
професор кафедри методики викладання іноземних мов й інформаційно-комунікаційних технологій, Київський національний лінгвістичний університет oksana.bihich@knlu.edu.ua

\title{
МЕТОДИЧНА СКАРБНИЧКА СТУДЕНТА-ПРАКТИКАНТА: ВСЕСВІТНІЙ ДЕНЬ КНИГИ В ЗАВДАННЯХ БЛОГІВ LACLASEDEELE.COM I PROFEDEELE.ES
}

В огляді проаналізовано пропоновані авторами блогів laclasedeele.com i profedeele.es завдання до Всесвітнього дня книги як потенційні для використання студентами бакалаврату й магістратури під час педагогічної практики з іспанської й інших іноземних мов у закладах середньої та вищої освіти. Сфоормульовано практичну мету кожного завдання. Акцентовано освітній і виховний потенціал пропонованих завдань.

Ключові слова: всесвітній день книги, педагогічна практика, іспанська мова.

Бигич Оксана Борисовна, доктор педагогических наук, профессор профессор кафедры методики преподавания иностранных языков и информационно-коммуникационных технологий, Киевский национальный лингвистический университет oksana.bihich@knlu.edu.ua

\section{МЕТОДИЧЕСКАЯ СОКРОВИЩНИЦА СТУДЕНТА- ПРАКТИКАНТА: МЕЖДУНАРОДНЫЙ ДЕНЬ КНИГИ В ЗАДАНИЯХ БЛОГОВ LACLASEDEELE.COМ И PROFEDEELE.ES}

В обзоре проанализированы предложенные авторами блогов laclasedeele.com и profedeele.es задания к Международному дню книги как потенциальные для использования студентами бакалаврата и магистратуры во время педагогической практики по испанскому и другим иностранным языкам в средней и высшей школе. Сформулирована практическая цель каждого задания. Акцентирован образовательный и воспитательный потенциал предложенных заданий.

Ключевые слова: международный день книги, педагогическая практика, испанский язык.

Bigych Oksana

Habilitated Doctor of Pedagogy, Full Professor, Full Professor of the Department of Foreign Languages Teaching Methods

Information and Communication Technologies Kyiv National Linguistic University oksana.bihich@knlu.edu.ua

METHODOLOGICAL TREASURY OF TRAINEE-STUDENT: INTERNATIONAL BOOK DAY IN LACSLASEDEELE.COM AND PROFEDEELE.ES BLOGS' TASKS

In the review the authors' tasks are analyzed within the blogs laclasedeele.com and profedeele.es in accordance with the International Book Day, as potential tasks that can be done during the students' teaching training in the Spanish and other languages in secondary and high schools. The practical aim of each task is formulated. The educational and upbringing potential of the proposed tasks are highlighted.

Key words: the International Book Day, teaching training, the Spanish language
Постановка проблеми. Поява нової спеціальності 014 Середня освіта галузі знань 01 Освіта / Педагогіка потребує навчально-методичного забезпечення процесу формування методичної компетентності в майбутніх учителів (перший (бакалаврський) рівень) і викладачів (другий (магістерський) рівень) іспанської мови. Навчально-методичного забезпечення потребує й така організаційна форма навчання студентів як педагогічна практика в закладах середньої (для студентів бакалаврату) й вищої (для студентів магістратури) освіти. Крім проведення уроків / аудиторних занять $з$ іспанської мови педагогічна практика передбачає обов'язкове проведення студентами-практикантами позакласного / позааудиторного заходу 3 іспанської мови.

Аналіз останніх досліджень і публікацій. Я вже аналізувала педагогічний аспект двох авторських блогів $з$ навчання іспанської мови laclasedeele.com i profedeele.es, зокрема структурну організацію їхніх дидактичних матеріалів (Бігич 2018).

Наразі метою статті $\epsilon$ аналітичний огляд завдань обох блогів, присвячених Всесвітньому дню книги як потенційних для використання студентами-практикантами як на уроці / аудиторному заняття, так і під час позакласного / позааудиторного за-

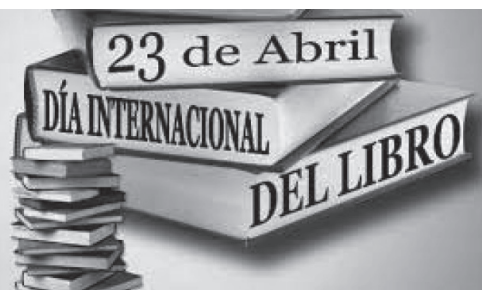
ходу з іспанської мови.

Виклад основного матеріалу дослідження. Згідно з рішенням ЮНЕСКО 1995 року щорічно 23 квітня відзначається Всесвітній день книги й авторського права.

Попри те, що на кінець квітня педагогічна практика студентів бакалаврату вже завершилася, а студентів магістратури ще не розпочалася, саме тому «El Día Internacional del Libro» вважаю константно актуальною як для уроку / аудиторного заняття 3 іспанської мови, так і для позакласного / позааудиторного заходу. 
Мій пріоритет у виборі саме цієї теми зумовлений низкою чинників. На жаль, у сучасних школярів і студентів, так званого покоління $Z$, утрачено навички вдумливого читання - вони швидко «сканують» тексти, не заглиблюючись у деталі прочитаного, без глибини розуміння змісту. I, можливо, пропоновані нижче завдання змінять їхнє ставлення до читання, зокрема іноземними мовами, і вони сприйматимуть книгу як універсальне джерело знань, надійний спосіб їх збереження та вагомий засіб їх поширення.

У цьому контексті студентів варто ознайомити 3 пам'ятниками книзі, встановленими в різних країнах світу, зокрема в Німеччині й Іспанії (рис. 1, 2).

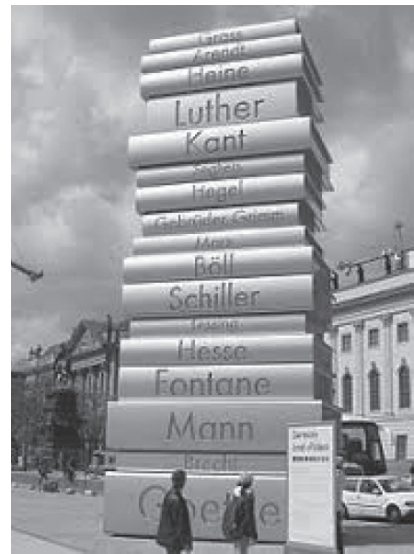

Рис. 1. Пам'ятник книгам у Берліні

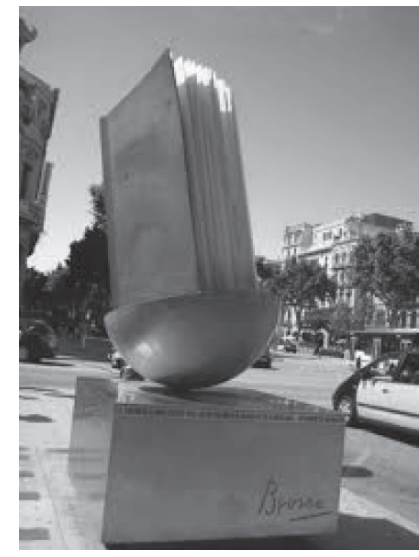

Рис. 2. Пам'ятник книзі в Барселоні
Саме в Іспанії в 1926 році було започатковане святкування Дня іспанської книги 23 квітня - у день смерті Сервантеса. 23 квітня, 1616 року помер і Шекспір. Також 23 квітня в Каталонії святкуються день Святого Георгія - аналог Дня Святого Валентина - Дня закоханих. Юнаки дарують коханим троянду, дівчата дарують коханим книгу. Починаючи з 1931 року під час традиційних книжкових ярмарків кожен покупець книги також отримує троянду. У такий спосіб це свято $є$ водночас і всесвітнім, і національним, що уможливлює його відзначення як під час вивчення іспанської, так і інших іноземних мов.

Не обійшли своєю увагою цей день й автори блогів laclasedeele.com i profedeele.es з навчання іспанської мови як іноземної. Так, Вероніка Тарантіно Парада, авторка блогу laclasedeele.com, презентує методичну розробку «20 ideas у recursos para celebrar el Día del libro» (Tarantino Parada, 2019), укладену для користувачів з середнім і просунутим рівнями володіння іспанською мовою. Пропоновані завдання, крім практичної мети як провідної, сприяють розширенню літературного світогляду школярів / студентів i спонукають їх до читання згаданих у завданнях та інших книг, реалізуючи в такий спосіб освітню / соціокультурну й виховну цілі.
На мою думку, ці завдання є універсальними, оскільки їх можна виконувати під час вивчення будь-якої теми, дібравши дотичну(i) до неї книгу(и). Водночас завдання укладено з урахуванням такого освітнього тренду як гейміфікація завдяки наявності елементів змагання на індивідуальну (завдання 1,5 , $11)$ й командну (завдання $3,4,7,11$ ) першість. Кожне пропоноване завдання, крім перекладу українською мовою (задля ознайомлення з ними широкого загалу читачів), я доповнила видом цільової для формування іспаномовної комунікативної компетентності.

1. Пишемо мінірозповідь 350 слів (Escribe una mini-historia en 50 palabras)

Практична мета - формування іспаномовної компетентності в письмі й читанні (для автора розповіді) й аудіюванні (для інших учасників)

Кожен школяр / студент пише коротку розповідь (максимум з 50 слів) і підписує її псевдонімом. Після прочитання всіх розповідей за результатами голосування обирають й нагороджують три найкращі. Також нагороджуються найрозважальніша, найдивніша, найправдивіша, найстрашніша, найвигадливіша розповіді.

2. Товкучка використаних книг (Mercadillo de libros usados en clase)

Кожен школяр / студент приносить 3 дому прочитану книгу для взаємообміну нею з однокласниками / одногрупниками чи навіть іншими школярами / студентами. Якщо ж книг багато, обов'язки можна розподілити: хтось збирає книги, хтось їх класифікує, хтось здійснює обмін тощо.

3. Кожен початок мас свос завершення (Todo inicio tiene su final)

Практична мета - формування іспаномовної компетентності в читанні й говорінні

На різних картках пишуться початок і кінець всесвітньо відомих і популярних книг. Школярі / студенти мають об'єднати початок і завершення однієї книги. Це завдання може проводитися у формі командного змагання. Інший варіант перебігу цього завдання - об'єднати початок і завершення однієї книги та її автора.

4. Оформи титульну сторінку (Diseña la portada) Практична мета - формування іспаномовної компетентності в аудіюванні й говорінні

Учитель / викладач повідомляє школярам / студентам назву книги іспаномовного автора й зачитує коротку анотацію, за змістом якої школярі / студенти 
мають зрозуміти ідею книги. Організовані в мінігрупи школярі / студенти оформлюють титульні сторінки для цієї книги, які пізніше порівнюються 3 титульною сторінкою оригіналу книги. Перемагає мінігрупа, чия титульна сторінка є найближчою до оригіналу / найкреативнішою.

5. Взасмообмін розповідями (Intercambio de historias)

Практична мета - формування іспаномовної компетентності в письмі й читанні (для авторів) й аудіюванні (для слухачів)

Кожен школяр / студент пише початок розповіді (5-10 рядків). Навмання школярі / студенти тричі обмінюються початками розповіді для їх продовження та завершення. Усі написані розповіді зачитують уголос для обрання й нагородження переможців - авторів найоригінальнішої / найдраматичнішої / найбільш розважальної / найстрашнішої тощо розповіді.

6. Усна презентація улюбленої книги (Presentación oral: Comparte tu libro favorite)

Практична мета - формування іспаномовноі компетентності в говорінні (для презентатора книги) й аудіюванні (для слухачів)

3 опертям на «Minipresentaciones para practicar la expresión oral» кожен школяр / студент коротко пре-

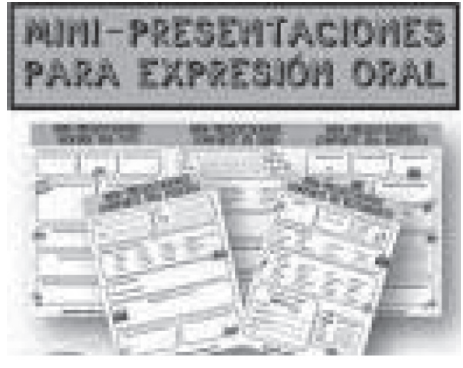
зентує свою улюблену книгу.

7. На полювання за книгами (A la caza de libros) Практична мета - формування іспаномовної компетентності в читанні

Якщо в закладі середньої / вищої освіти є бібліотека, учитель / викладач готує маленькі аркуші чи клейкі папірці. Мінігрупи (3-4 особи) школярів / студентів мають знайти 3-поміж книг у бібліотеці секретне послання, яке викладач / учитель сховав в одній 3 них. Виграє мінігрупа, яка його знайде першою.

8. Причини, щоб читати (Razones para leer (mural)) Практична мета - формування іспаномовної компетентності в письмі й читанні

Учитель / викладач пропонує школярам / студентам зробити стіннівку «Наші 30 причин, щоб читати» («Nuestras 30 razones para leer»). Стіннівка може бути прикрашена власними малюнками чи вирізками 3 журналів. Це завдання є різновидом проєктної роботи.
9. Тлумачення змісту книги (Interpreta tu libro)

Практична мета - формування іспаномовної компетентності в письмі

Школярі / студенти організуються в мінігрупи (максимум по 5 осіб). Кожна мінігрупа обирає книгу, яку мімічно / німим театром витлумачує іншим мінігрупам. Попередньо укладається перелік книг, прочитаних школярами / студентами, які були екранізовані, є дуже популярними чи всесвітньо відомими.

10. Інтерв’ ювання автора твосї улюбленої книги (Entrevista al autor de tu libro favorite)

Практична мета - формування іспаномовної компетентності в діалогічному мовленні

Організовані в мінігрупи школярі / студенти обмірковують можливі запитання улюбленому іспаномовному письменнику з опертям на шаблон «Preparando una entrevista a un escritor famoso». Після чого в форматі рольової гри розігрують інтерв'ю.

11. Вгадай головного персонажа (Identifica el personaje principal)

Практична мета - формування іспаномовної компетентності в монологічному мовленні

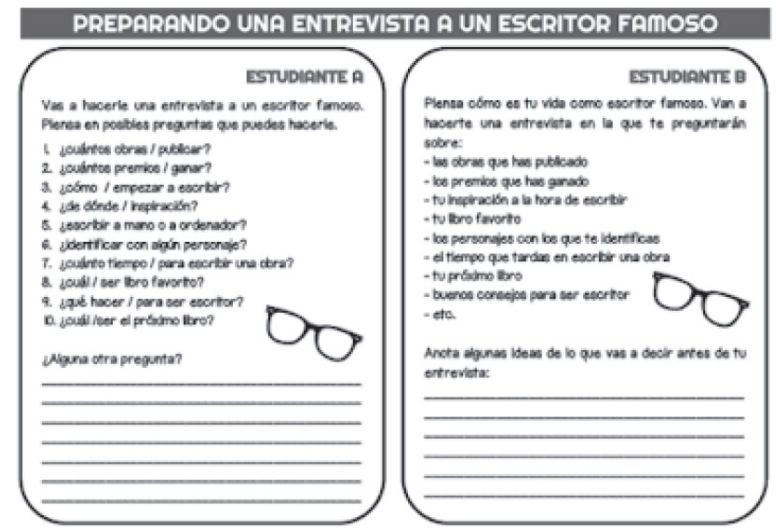

Учитель / викладач показує школярам / студентам світлини головних персонажів відомих книжок, екранізованих у кіно. Вони мають здогадатись і назвати ім'я головного персонажа, автора й назву книги. За кожну правильну відповідь нараховується бал. Перемагає група / пара чи школяр / студент, яка(ий) набере найбільше балів.

12. Твітни твою улюблену книгу в 150 знаків (Twittea tu libro favorito en 150 caracteres)

Практична мета - формування іспаномовної компетентності в письмі

У шаблоні Твітер школярі / студенти описують улюблену книгу чи недавно прочитану 3
PLANTILLA TUITTER

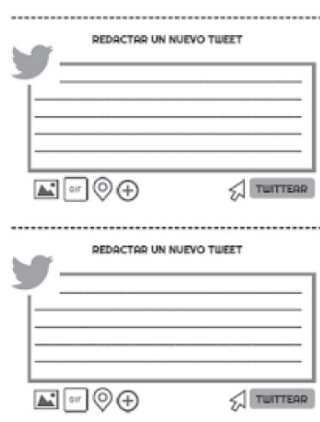


метою зацікавити потенційних читачів цією книгою, використавши всього 150 знаків.

13. Трейлер твоєї улюбленої книги (Tráiler de tu libro favorito)

Практична мета - формування іспаномовної компетентності в письмі

3 опертям на Power Point чи іншу програму створення відео (Powtoon / Animoto) школярі / студенти укладають трейлер улюбленої книги.

14. Книга, перетворена в комікс (Un libro convertido en comic)

Практична мета - формування іспаномовної компетентності в письмі

3 опертям на програму розроблення коміксів (Witty Comics / Pixton) школярі / студенти укладають короткий комікс про улюблену книгу.

15. Подаруй закладку (Regala un marcapáginas)

Практична мета - формування іспаномовної компетентності в письмі

Школярі / студенти виготовляють закладки з відомими цитатами іспанською мовою про користь читання (посилання «27 Marcadores con citas célebres para el Día del Libro»)

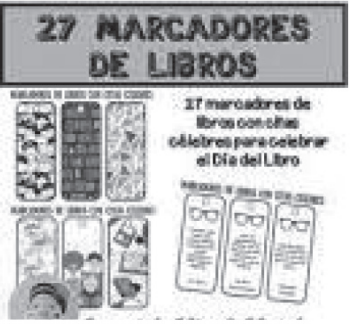

16. Швидкий зміст книги (Cita rápida sobre libros)

Практична мета - формування іспаномовної компетентності в монологічному мовленні

Кожен школяр / студент приносить копію чи зображення титульної сторінки своєї улюбленої книги. Протягом 2-3 хв. він має пояснити своєму напарнику зміст книги, доки не пролунає дзвоник для зміни в парі. Кожен школяр / студент має обрати 1-5 книг, які його зацікавили, й остаточно вирішити, якуз них буде читати. Для успішного виконання завдання школярам / студентам пропонується заповнити шаблон «Cita rápida sobre libros»».

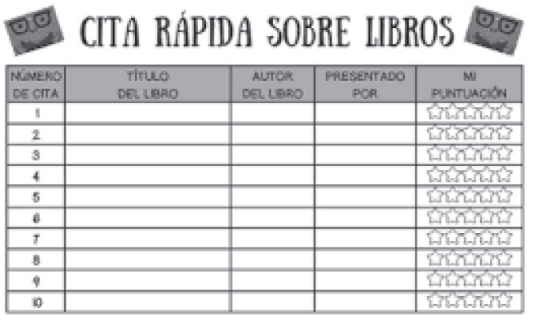

El URRO QUE EUIO ES
17. А чому ти віддаєш перевагу? (Y tú, ¿Qué prefieres?)

Практична мета - формування іспаномовної компетентності в монологічному мовленні
Учитель / викладач з опертям на розмовні картки «Tarjetas de conversación para el Día del Libro ¿Qué prefieres?» організовує обговорення школярами / студентами їхніх звичок читання.

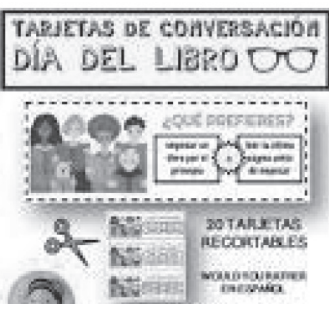

18. Мапи про літературу (Mapas sobre literatura)

Практична мета - формування іспаномовної компетентності в монологічному мовленні

Чому б не дослідити літературні твори засобом мапи? На наведених веб-сторінках («Literature Map of the World» («Mapa mundial de la literatura»); «De viaje literario por España: Una lectura por cada provincia») можна прослідкувати найбільш знакові книги кожної країни і кожної провінції Іспанії.

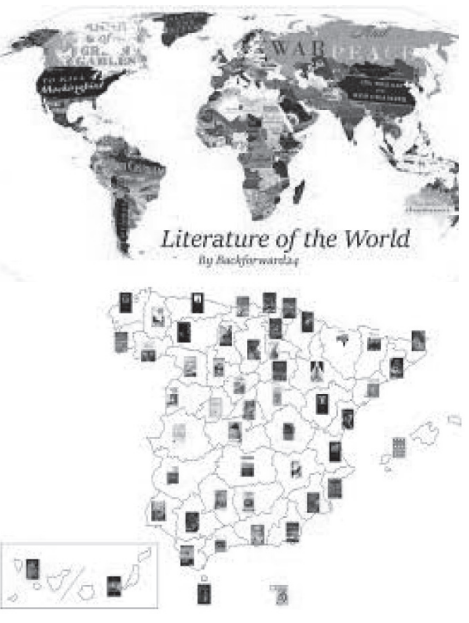

19. Короткометражки для розвитку читання (Cortos para fomentar la lectura)

Практична мета - формування іспаномовної компетентності в монологічному мовленні

Перегляд короткометражного фільму / відео завжди слугує хорошим приводом, щоб зацікавити школярів / студентів і спонукати їх до читання. (Короткометражні мультфільми «The Fantastic Flying Books of Mr. Morris Lessmore» (переможець Оскара 2012 p.); «Much better now»; «Leer en corto» Ha Youtube).

20. Супер-пакунок 310 завданнями для святкування Дня книги (Super-pack con 10 actividades para celebrar el Día del Libro)

\begin{tabular}{|c|c|}
\hline $\begin{array}{l}\text { Завдання } 1 . \\
\text { Практична мета - фор- } \\
\text { мування іспаномовної } \\
\text { компетентності в діало- } \\
\text { гічному й монологічному } \\
\text { мовленні }\end{array}$ & $\begin{array}{l}\text { Школярі / студенти в групі } \\
\text { обговорюють святкування } \\
\text { Дня книги. Після чого укла- } \\
\text { дають власну версію легенди } \\
\text { про Святого Георгія і дра- } \\
\text { кона, використовуючи такі } \\
\text { лексичні одиниці: lanza, rosa, } \\
\text { princesa, castillo, caballero, } \\
\text { dragón, escudo, sangre, duelo. }\end{array}$ \\
\hline $\begin{array}{l}\text { Завдання } 2 . \\
\text { Практична мета - фор- } \\
\text { мування іспаномовної } \\
\text { компетентності в моно- } \\
\text { логічному мовленні }\end{array}$ & $\begin{array}{l}\text { Школярі / студенти рекомен- } \\
\text { дують для читання } 11 \text { різних } \\
\text { книг } 3 \text { опертям на низку об- } \\
\text { раних критеріїв. }\end{array}$ \\
\hline
\end{tabular}




\begin{tabular}{|c|c|}
\hline $\begin{array}{l}\text { Завдання } 3 . \\
\text { Практична мета - фор- } \\
\text { мування іспаномовної } \\
\text { компетентності в моно- } \\
\text { логічному презентацій- } \\
\text { ному мовленні }\end{array}$ & $\begin{array}{l}\text { Школярі / студенти готують } \\
\text { візуальний супровід усної } \\
\text { презентації улюбленої книги }\end{array}$ \\
\hline $\begin{array}{l}\text { Завдання } 4 . \\
\text { Практична мета - фор- } \\
\text { мування іспаномовної } \\
\text { компетентності в письмі }\end{array}$ & $\begin{array}{l}\text { Школярі / студенти виготов- } \\
\text { люють постер з розміркову- } \\
\text { ваннями про вагомість чи- } \\
\text { тання, в якому висловлюють } \\
\text { власні думки про причини } \\
\text { обов'язкового читання, вико- } \\
\text { ристовуючи } 25 \text { дієслів. }\end{array}$ \\
\hline $\begin{array}{l}\text { Завдання } 5 . \\
\text { Практична мета - фор- } \\
\text { мування іспаномовної } \\
\text { лексичної компетент- } \\
\text { ності }\end{array}$ & $\begin{array}{l}\text { Учитель / викладач укладає } \\
\text { список } 20 \text { слів, пов'язаних зі } \\
\text { світом книг. Школярі / сту- } \\
\text { денти співвідносять слова } 3 \\
\text { іхнім тлумаченням. } \\
\end{array}$ \\
\hline $\begin{array}{l}\text { Завдання } 6 . \\
\text { Практична мета - фор- } \\
\text { мування іспаномовної } \\
\text { компетентності в письмі }\end{array}$ & $\begin{array}{l}\text { Школярі / студенти заповню- } \\
\text { ють картку з інформацією про } \\
\text { книгу, яку планують подару- } \\
\text { вати / обміняти. }\end{array}$ \\
\hline $\begin{array}{l}\text { Завдання } 7 . \\
\text { Практична мета - фор- } \\
\text { мування іспаномовної } \\
\text { лексичної компетент- } \\
\text { ності }\end{array}$ & $\begin{array}{l}\text { Школярі / студенти іден- } \\
\text { тифікують і класифікують } \\
\text { прикметники для опису книг. }\end{array}$ \\
\hline $\begin{array}{l}\text { Завдання } 8 . \\
\text { Практична мета - фор- } \\
\text { мування іспаномовної } \\
\text { компетентності в моно- } \\
\text { логічному мовленні }\end{array}$ & $\begin{array}{l}\text { Школярі / студенти обго- } \\
\text { ворюють щойно прочитані } \\
\text { книги. }\end{array}$ \\
\hline $\begin{array}{l}\text { Завдання } 9 . \\
\text { Практична мета - фор- } \\
\text { мування іспаномовної } \\
\text { компетентності в моно- } \\
\text { логічному мовленні } \\
\end{array}$ & $\begin{array}{l}\text { 3-поміж } 20 \text { книг, які найбільш } \\
\text { читаються у світі, школярі } \\
\text { / студенти обирають ті, які } \\
\text { знають чи читали. }\end{array}$ \\
\hline $\begin{array}{l}\text { Завдання } 10 . \\
\text { Практична мета - фор- } \\
\text { мування іспаномовної } \\
\text { компетентності в діа- } \\
\text { логічному й монологіч- } \\
\text { ному мовленні }\end{array}$ & $\begin{array}{l}\text { Школярі /студенти організо- } \\
\text { вуються в пари / мінігрупи, у } \\
\text { яких обговорюють свої пре- } \\
\text { ференції, погляди й звички } \\
\text { читання. Обговорення триває } \\
4 \text { короткі сети з } 10 \text { запитання- } \\
\text { ми до кожного. }\end{array}$ \\
\hline
\end{tabular}

Пропоновані вище завдання передбачають фізичну присутність у класі / аудиторії обох суб’єктів освітнього процесу: школярів / студентів і вчителя / викладача іспанської мови. Водночас низка об'єктивних (дистанційне навчання) і суб'єктивних (відкритість сучасних школярів / студентів до новітніх технологій і віртуальної комунікації) чинників актуалізує методичну розробку Федеріко Ескудеро Альвареса (Federico Escudero Álvarez, 2020) 15 інтерактивних завдань, укладених для користувачів з мовними рівнями В1-В2, яку Даніель Руіс Ернандес розмістив у своєму блозі profedeele.es.
У кожному завданні, крім його перекладу на українську мову, я визначила практичну мету. Цільовими для формування в цих завданнях $є$ іспаномовні лексична й граматичні компетентності та компетентність у техніці письма, а також мовленнєві компетентності в діалогічному й монологічному мовленні, читанні й аудіюванні.

Крім практичної мети, як провідної, пропоновані завдання спрямовані на реалізацію яскраво виражених освітньої / соціокультурної (сприяють розширенню літературного світогляду школярів / студентів) й виховної (спонукають їх до читання згаданих у завданнях й інших книг) цілей.

Завдання, спрямовані на формування іспаномовних лексичної й граматичної компетентностей, $\epsilon$ власне тестами перехресного (matching test) i множинного (multiple choice test) вибору. Використовувані в цих завданнях одиниці навчання надалі передбачають їх опрацювання школярем / студентом на рівні міні-тексту, реалізуючи в такий спосіб навчальний прийом «сніжка» (snowball).

3 огляду на інтерактивність пропонованих завдань режим їх виконання передбачає індивідуальне опрацювання школярем / студентом навчального матеріалу з власного гаджета. Виняток становлять завдання, метою яких $є$ формування компетентності в діалогічному мовленні, мовленнєву взаємодію користувачів у яких й уможливлюють сучасні технології.

Водночас інтерактивний формат низки завдань унеможливлює відтворення їхнього ілюстративного матеріалу, тому обмежусь його вербальним описом.

\section{Завдання 1. Поговоримо про книги (Hablemos de libros)}

Практичнамета-формування компетентності в діалогічномумовленні (на рівні діалогічної сдності)

Ти - у віртуальній бібліотеці, на полицях якої можеш знайти різні книжки. Співвіднеси їхні титульні сторінки $з$ дотичними жанрами.

\begin{tabular}{|l|l|}
\hline & $\begin{array}{l}\text { Зображення титульних сторінок таких } \\
\text { книг: }\end{array}$ \\
\hline Novela fantástica & Harry Potter y el cáliz de fuego \\
\hline Biografía & Buñuel en el laberinto de las tortugas \\
\hline Ensayo & La isla del tesoro \\
\hline Novela de ciencia ficción & El amor en los tiempos del cólera \\
\hline Novela gráfica o comic & Stephen King \\
\hline Novela detectivesca & The adventures of Sherlock Holmes \\
\hline Libro de autoayuda & El gran libro rojo \\
\hline Novela histórica & Jurassic Park \\
\hline Novela de aventuras & Frida Kahlo \\
\hline Novela de terror & Trilogía de Aléxandros \\
\hline Poenario & $\begin{array}{l}20 \text { poemas de amor y una canción } \\
\text { desesperada }\end{array}$ \\
\hline Novela romantic & Ensayos filosóficos \\
\hline
\end{tabular}

Визнач жанр кожної книги на кшталт:

"Los juegos del hambre" es novela fantástica, ¿no?

Sí, y también "El señor de los anillos". 
Завдання 2. Не суди про книгу лише за її титульною сторінкою (No juzgues un libro solo por la portada)

Практична мета - формування лексичної компетентності

Висловлюючи думку про книгу за їі зовнішнім виглядом, ми говоримо «juzgamos un libro solo por la portada». Перевір знання тематичних слів щодо книги як об'єкта.

\begin{tabular}{|l|l|}
\hline Cubierta de un libro & La portada y la contraportada \\
\hline Contraportada de un libro & $\begin{array}{l}\text { Portada de un libro donde aparece el } \\
\text { titulo y el nombre del autor }\end{array}$ \\
\hline Tapas de un libro & Parte opuesta al cortede las hojas \\
\hline Solapa de un libro & $\begin{array}{l}\text { Prolongación lateral de la portada que } \\
\text { se dobla hacia adentro normalmente con } \\
\text { contenido publicitario }\end{array}$ \\
\hline Lomo de un libro & $\begin{array}{l}\text { Cubierta trasera de un libro donde suele } \\
\text { haber información del autor y la obra }\end{array}$ \\
\hline Faja un libro & $\begin{array}{l}\text { Objeto que sirve para señalar una página } \\
\text { donde se interrumpió la lectura }\end{array}$ \\
\hline Marcapáginas & $\begin{array}{l}\text { Tira de papel sobre la cubierta de un libro } \\
\text { donde se hace referencia a un premio } \\
\text { recibido o a su contenido }\end{array}$ \\
\hline
\end{tabular}

Завдання 3. Книга як об’єкт (El libro como objeto) Практична мета - формування лексичної компетентності

Поєднай слова 3 попередньої вправи з їхніми зображеннями.

\begin{tabular}{|l|l|}
\hline Cubierta de un libro & $\begin{array}{l}\text { Ілюстративні зображення цих лек- } \\
\text { сичних одиниць }\end{array}$ \\
\hline Contraportada de un libro & \\
\hline Tapas de un libro & \\
\hline Solapa de un libro & \\
\hline Lomo de un libro & \\
\hline Faja de un libro & \\
\hline Marcapáginas & \\
\hline
\end{tabular}

Завдання 4. Шляхи читання (Maneras de leer)

Практичні цілі - формування лексичної компетентності та компетентності в діалогічному мовленні

Переходимо від того, шо ми читаємо, до того, як ми читаємо. Ліворуч розташовано вирази, дотичні до поверхового читання (de refilón), праворуч - вдумливого читання (concienzudamente).

- ¿Con cuál de ellas te identificas tú? (3 яким способом читання ти корелюєш себе?)

- ¿Cambia tu forma de leer en función del tipo de texto que lees? (Чи змінюється твій спосіб читання залежно від типу тексту, який ти читаєш?)

- ¿Cambia tu forma de leer en función de si lees en formato papel o digital? (Чи змінюється твій спосіб читання залежно від того, читаєш ти паперовий чи електронний варіант?)
Завдання 5. Молодь і читання (Los jóvenes y la lectura)

Практична мета - формування компетентності в аудіюванні

Подивись відео з журналістом і письменником Себастьяном Гарсіа Муретом (Sebastián García Mouret), у якому йдеться про читання й молодь. Дивлячись відео, подумай над відповідями на запитання, які будуть з'являтись.

Завдання 6. День книги (El Día del Libro)

Практичні цілі-формування компетентностей в читанні й аудіюванні

Якщо ти є завзятим читачем, то маєш знати, що 23 квітня є днем книги, оскільки в цей день нібито померли Мігель де Сервантес і Вільям Шекспір. Якщо хочеш дізнатися більше, можеш прочитати статтю Хорхе Гутієреса Гамона (Jorge Gutiérrez Gamón) в журналі Habla (режим доступу https://www. revistahabla.com/23-de-abril-dia-internacional-del-libro/.

Крім того, кожне 23 квітня вулиці по всій Іспанії заповнюються книжковими ярмарками, а у Барселоні - крім книг, і трояндами. Знаєш, чому? Подивись відео, щоб дізнатись.

Завдання 7. Хочу книгу, яка ...(Quiero un libro que...)

Практична мета - формування граматичної компетентності

Опрацюй ці два речення:

En casa: Busco el libro que tiene ilustraciones. (Si, hombre, ese libro infantil que tiene esos dibujos tan bonitos)

En una librería: Busco un libro que tenga ilustraciones. (Es para un niño de seis años)

У першому випадку ми говоримо про відомий факт (книга, у якій $є$ ілюстраціі).

У другому випадку ми говоримо про невідомий факт (книга, у якій, можливо, є ілюстрації).

Орієнтуючись на викладене вище, обери з-поміж речень їх правильну інтерпретацію чи правильне продовження:

1. (A un bibliotecario): Busco un libro de gramática que tiene muchos ejercicios.

- No tengo ni idea de qué libro de gramática es.

- Es ese libro de gramática que me ha recomendado mi profesor, pero no me acuerdo de su título exacto.

2. (A un dependiente de una librería): Quiero un libro que sea apto para niños de seis años.

- No sé qué libro escoger. ¿Me puede recomendar uno?

- Sé exactamente a qué libro me refiero

3. (En una librería): Quiero hablar con un dependiente que sabe mucho de libros. 
- Sé quién es pero no recuerdo su nombre.

- No tengo ni idea de quién puede ayudarme.

4. Lo que dice Ana sobre la última novela de Isabel Allende me interesa mucho. Lo que diga Luis no me importa.

- Conoce la opinión de Luis pero no la de Ana.

- Conoce la opinión de Ana pero no la de Luis.

- No conoce la opinión de Luis ni de Ana.

5. ¿Por qué no vamos a la caseta que vende libros de segunda mano?

- No sé si hay una caseta que venda libro de segunda mano.

- Es la que está al fondo a la izquierda.

6. Quiero regalar a Juan un libro que tenga una historia romántica.

- Todavía no he decidido cuál.

- El último libro de Isabel Allende.

Завдання 8. Практикуючись у контексті (Practicando en contexto)

Практична мета - формування компетентності в діалогічному мовленні

Наразі попрактикуйся у використанні попереднього граматичного явища в діалозі.

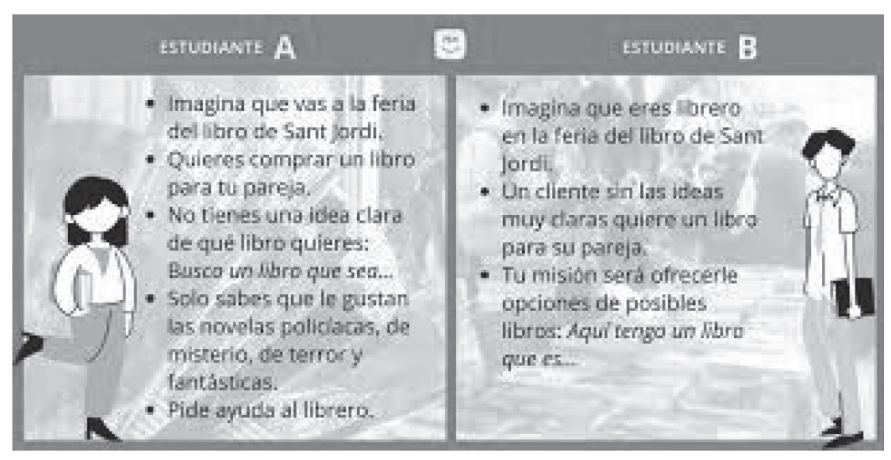

\section{Завдання 9. Ідеальна книга (EI libro ideal)}

Практична мета - формування компетентностей у читанні й монологічному мовленні

Прочитай адаптований варіант поеми лауреата Нобелівської премії Хуана Рамона Хіменеса (Juan Ramón Jiménez).

Quiero que mi libro sea, como es el cielo por la noche, todo verdad presente, sin historia. Que, como él, se dé en cada instante, todo, con todas sus estrellas; sin que niñez, juventud, vejez quiten ni pongan encanto a su hermosura inmensa.

¡Temblor, relumbre, música presentes y totales!

¡Temblor, relumbre, música en la frente

— cielo del corazón - del libro puro. Piedra y cielo de Juan Ramón Jiménez
Хуан Рамон Хіменес описує в поемі, якою він хотів би бачити ідеальну книгу. А якою бачиш ти ідеальну для тебе книгу?

Завдання 10. Про книги й авторів (De libros y de autores)

Практична мета - формування компетентності в читанні

Як тобі вже відомо, 23 квітня померли Мігель де Сервантес (Miguel de Cervantes) і Уільям Шекспір (William Shakespeare). Ознайомся з іншими представниками іспанської й світової літератури.

1. Poeta italiano del siglo XIV, su obra más conocida es la Divina Comedia en la que relata su viaje ficticio por el infierno, el purgatorio y el paraíso. Las horrorosas escenas de torturas descritas en el infierno tienen una gran fuerza e intensidad.
a. Fernando de Rojas
b. Nicolás Maquiavelo
c. Dante Aligueri

2. Dramaturgo español de finales del siglo XV, es el autor de La Celestina. Calixto, un joven noble, contrata a una vieja bruja llamada Celestina para que le ayude a seducir a Melibea.
a. Tirso de Molina
b. Miguel de Cervantes
c, Fernando de Rojas

3. Filósofo italiano de teoría política, su obra más conocida es El príncipe, en la que retrata al gobernante ideal: astuto, oportunista y manipulador. Aunque nunca lo dijo, la frase El fin justifica los medios resume muy bien su teoría política.
a. Nicolás Maquiavelo
b. Marqués de Sade
c. Dante Alighier

4. El Lazarillo de Tormes es el prototipo de la llamada novela picaresca. En ella se cuentan las aventuras y desventuras de un pícaro, un personaje de clase baja que vive (o sobrevive) engañando, mintiendo y robando. En esta novela el capítulo más conocido es en el que el niño Lázaro sirve de guía y acompañante a un ciego.
a. Tirso de Molina
b. Fernando de Rojas
c. Autor anónimo

5. Dramaturgo inglés, una de sus obras más conocidas es Romeo y Julieta, que ha pasado a simbolizar el amor imposible de dos adolescentes enamorados de familias rivales.
a. Marqués de Sade
b. Frank Kafka
c. William Shakespeare 
6. Fue escritor de teatro, poesía pero sobre todo de novela. En su obra más conocida Alonso Quijano se vuelve loco de tanto leer novelas de caballería y se convierte en Don Quijote de la Mancha. Representa al idealista que lucha para cambiar la realidad.
a. Autor anónimo
b. Tirso de Molina
c. Miguel de Cervantes

7. Escritor de teatro español, es el creador de Don Juan Tenorio, prototipo de seductor. Es un caballero sevillano que ha seducido a todo tipo de mujeres excepto a una: la monja.
a. Tirso de Molina
b. Fernando de Rojas
c. Autor anónimo

8. Aristócrata francés, en sus obras relata escenas de sexo explícito en la que los protagonistas son humillados.
a. Marqués de Sade
b. Dante Aligheri
c. Leopold Masoch

9. Escritor austriaco, en su novela La Venus de las pieles, relata una relación basada en la dominación de Severin por parte de su amante Wanda. Él le pide a ella que le trate como un esclavo y le produzca dolor.
a. Leopold Masoch
b. Marqués de Sade
c. William Shakespeare

10. Escritor checo, sus obras se caracterizan por las situaciones absurdas y angustiosas. Un ejemplo es $L a$ metamorfosis, donde un joven despierta convertido en un monstruoso insecto.
a. Frank Kafka
b. El marqués de Sade
c. Leopold Masoch

Завдання 11. Про авторів і персонажів (De autores y personajes)

\section{Практична мета - формування компетентнос- ті в читанні}

Співвіднеси зображення й імена літературних персонажів:

\begin{tabular}{|l|l|}
\hline Don Juan Tenorio & Зображення кожного \\
\hline Dante Alighieri & літературного персо- \\
\hline Frank Kafka & \\
\hline El marqués de Sade & \\
\hline Romeo & \\
\hline Don Quijote de la Mancha & \\
\hline Leopold Von Sacher-Masoch & \\
\hline Maquiavelo & \\
\hline El Lazarillo de Tormes & \\
\hline La Celestina & \\
\hline
\end{tabular}

\section{Завдання 12. Епоніми (Epónimos)}

Практична мета - формування лексичної ком-

\section{петентності}

$€$ настільки відомі персонажі й автори, що їхні імена стають загальними. Наприклад, Casanova як синонім спокусника. Такі слова називають епонімами - власні імена, які стають загальними. При цьому, хоча епоніми й походять від власних імен, вони пишуться з малої літери. Так, Don Juan Tenorio як епонім пишеться як donjuán (разом і з наголосом).

Поєднай епоніми з їхніми тлумаченнями:

\begin{tabular}{|l|l|}
\hline Ser algo dantesco & $\begin{array}{l}\text { Ser alguien a quien le gusta el } \\
\text { sufrimiento }\end{array}$ \\
\hline Ser una calestina & $\begin{array}{l}\text { Ser una situación angustiosa y } \\
\text { surrealista }\end{array}$ \\
\hline Ser maquiavélico & Ser un espectáculo espantoso y horrible \\
\hline Ser un lazarillo & $\begin{array}{l}\text { Ser alguien que disfruta siendo torturado } \\
\text { y humillado }\end{array}$ \\
\hline Ser un romeo & Ser un seductor \\
\hline Ser un quijote & Ser un galán enamorizado \\
\hline Ser un donjuán & $\begin{array}{l}\text { Ser el perro o muchocho que guía y } \\
\text { acompaña a un ciego }\end{array}$ \\
\hline Ser un sádico & Ser idealista \\
\hline Ser masoquista & $\begin{array}{l}\text { Ser alguien que piensa que el fin justifica } \\
\text { los medios }\end{array}$ \\
\hline Ser algo kafkiano & $\begin{array}{l}\text { Ser una mujer que media entre dos } \\
\text { personas para que inicien una relación } \\
\text { amorosa }\end{array}$ \\
\hline
\end{tabular}

Завдання 13. Епоніми 2 (Epónimos II)

Практична мета-формування компетентності в техніці письма

Заповни пропуски епонімами з попереднього завдання. Пам'ятай про їх написання з малої літери.

1. Alicia siempre intenta formar parejas entre sus amigos. Es una

2. Luis está hecho un seductor. Flirtea con todas las chicas. Es un

3. El abuelo de Marcos se está quedando ciego debido a las cataratas. Marcos le acompaña y le sirve de

4. Cuando fui corresponsal de guerra pude ver el espectáculo de las matanzas durante la guerra de los Balcanes.

5. Dios mío, el otro día estuve toda la mañana de un piso a otro de la dirección de tráfico para renovar mi carné de conducir. Ni ellos mismos se aclaraban con el procedimiento administrativo. Fue una situación completamente

6. Los psicópatas tienen una ausencia absoluta de empatía y les es indiferente o incluso disfrutan con el sufrimiento ajeno. Tienen un componente 
7. Álvaro siempre está metido en ONGs y en proyectos de cooperación. Considera que hay que actuar para cambiar la realidad. Es un

8. Es un político completamente $\mathrm{Ha}$ basado su carrera en la manipulación y la mentira.

9. Está atrapado en una relación tóxica. Parece como si le gustara ser dominado por alguien. Es un

10. Uy, mira, allí viene Ángel con un ramo de flores para ti. Ahí tienes a tu

\section{Завдання 12.}

Практична мета - формування компетентності в діалогічному мовленні

Наразі опрацюй епоніми з попереднього завдання в контексті. Спробуй використати один з попередніх епонімів у реченні. Твої одногрупники мають здогадатись, який епонім ти маєш на увазі.

- ¿Sabes que Laura y Leo empezaron a salir gracias a Luisa? Ella insistió a Laura en presentarle a Leo. Le decía, ya verás, tenéis mucho en común, a los dos os encanta leer...

- Luisa es una celestina.

- Exacto.

Також порозмірковуй, чи є якийсь літературний персонаж, який став епонімом у твоїй мові?

Завдання 14. Пийте старі вина, читайте старі книги (Bebed viejos vinos, leed viejos libros)

Практична мета-формування компетентності в читанні

Приказка «Пийте старі вина, читайте старі книги» означає, що вино з роками стає якіснішим, а читання класичних книг є корисним. Ознайомся 3 іншими приказками про книги й читання.

Поєднай початок і закінчення приказок:

\begin{tabular}{|l|l|}
\hline Amigos y libros, & o roto o manchado \\
\hline Libro prestado, & averigua qué libros suele leer \\
\hline Si a tu vecino quieres conocer, & dan a los hombres sabituría \\
\hline Libros caminos y días, & pocos y Buenos \\
\hline $\begin{array}{l}\text { El que lee mucho y anda } \\
\text { mucho, }\end{array}$ & la vida te enseñará \\
\hline Lo que en los libros no está & ve mucho e sabe mucho \\
\hline
\end{tabular}

Завдання 15. Про читачів і про книги (De lectores y de libros)

Практична мета - формування компетентності в діалогічному мовленні

Дай відповіді на запитання опитувальника щодо твоєї читацької біографії й читацьких смаків:

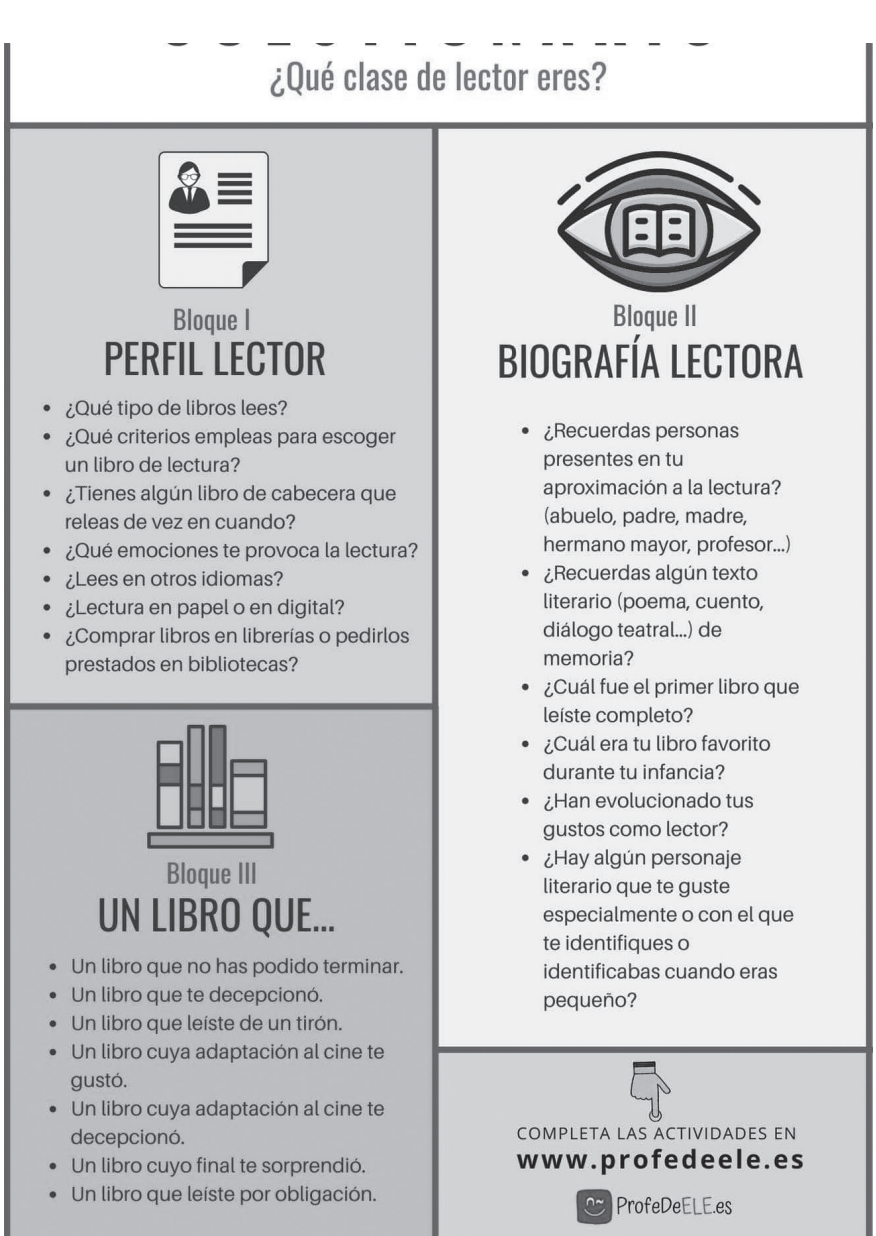

Ти маєш можливість обрати один з трьох режимів роботи:

1) якщо працюватимеш один(на), ти можеш редагувати текст своїми відповідями й надіслати їх учителю / викладачеві;

2) якщо працюватимеш один(на), можеш записати свої усні відповіді;

3) якщо працюватимеш з однокласниками / одногрупниками, можете інтерв'ювати один одного і записати (на електронний носій) ваші усні відповіді.

3 огляду на таку особливість покоління Z як складність сприйняття ним інформації на слух, до презентованого вчителем / викладачем навчального матеріалу висувається вимога його унаочнення у вигляді яскравої й барвистої візуалізації. Тому залежно від рівня навчання іспанської мови пропоновані вище завдання вчитель / викладач може доповнити низкою інтернет-ресурсів.

Так, ресурс VideoEle (режим доступу https:// videoele.com/B1-Dia-del-libro.html) для користувачів 3 рівнем володіння іспанською мовою В 1 пропонуе відео «El día del libro. Nivel B1». Його лексичним наповненням $€$ літературні жанри й теми; соціокультурний зміст представлено «Leyenda de San Jorge. Día de Sant 
Jordi en Cataluña. Firma de libros de autores conocidos. Medios de comunicación». Для полегшення розуміння змісту відео супроводжує транскрипт аудіотексту.

Tío Spanish, уже досліджуваний (Бігич, 2012; Бігич, Заїка, 2019) віртуальний учитель / викладач іспанської мови у вигляді пальця (режим доступу http://www. tiospanish.com), також пропонує відео «Día del libro», 3 якого користувачі ресурсу знайомляться з історією виникнення цього свята.

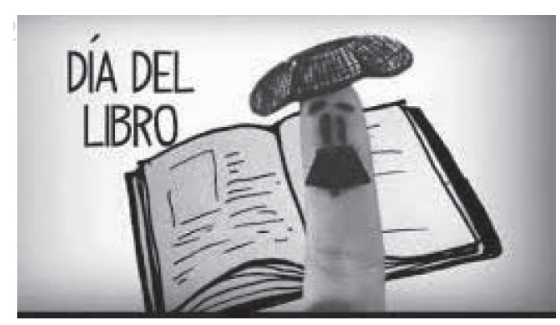

Безперечно, перерахувати всі інтернет-ресурси, дотичні до Всесвітнього дня книги, неможливо. Кожен 3 них націлений на користувача 3 певним рівнем володіння іспанською мовою, і вчитель / викладач завжди має можливість обрати той чи той ресурс з урахуванням особливостей саме своїх учнів / студентів.

Результати дослідження. Таким чином, крім практичної мети - формування різних видів мовних і мовленнєвих компетентностей, безперечним є освітній і виховний потенціал завдань, пропонованих авторами професійних блогів з навчання іспанської мови www.laclasedeele.com i www.profedeele.com. Завдання можуть бути використані студентами-практикантами на будь-якому уроці / аудиторному занятті іноземної мови чи позакласному / позааудиторному заході за умови дотичності обраної книги до виучуваної школярами / студентами теми.

Перспективи подалыших наукових розвідок убачаю в розробленні методичних проєктів, присвячених Всесвітньому дню книги, на кшталт методичного проєкту «Азбука квітів» (Бігич, 2016) для молодших школярів.

\section{СПИСОК ПОСИЛАНЬ}

Бігич, О. Б. (2018а). Авторські блоги викладачів іспанської мови: суперники чи соратники. Іноземна мова у професійній підготовці спеціалістів: проблеми та стратегії: Збірник тез доповідей II Міжнародної науково- практичної інтернет-конфреренції. - Кропивницький: РВВ ЦДПУ імені Володимира Винниченка, 23-25.

Бігич О. Б., Заїка В.В.(2019). Аналітичний огляд навчальних матеріалів «Tío Spanish: Aprender Español Online». Вісник КНЛУ. Серія Педагогіка та психологія, Вип. 30, 2019, 196-202

Бігич, О. Б. (2018б). Вибіркова дисципліна «Сучасні засоби навчання іспанської мови в закладі середньої освіти»: удосконалення методичної компетентності вчителя. Актуальні питання гуманітарних наук: Міжвузівський збірник наукових праць молодих вчених Дрогобицького державного педагогічного університету імені Івана Франка, 20( 1), 89-91.

Бігич, О. Б. (2016). Методичний проект для учителя початкової школи «Азбука квітів - El abecedario de flores / The flowers ABC». Іноземні мови, 2015, 3, 45-52.

Бігич, О. Б. (2012). Tío Spanish - віртуальний учитель / викладач іспанської мови. Іноземні мови, 2016, 2, 10-13.

Tarantino Parada V. (2019). 20 ideas y recursos para celebrar el Día del libro / Recuperado de https://www.laclasedeele. com/2019/04/20-ideas-y-recursos-para-celebrar-el.html

Escudero Álvarez F. (2020). Día del libro: unidad didáctica interactica / Recuperado de https://www.profedeele.es/ actividad/cultura/dia-del-libro-23-abril/

\section{REFERENCES}

Bigich, O. B. (2018a). Avtors'ki blogi vikladachiv ispans'koï movi: superniki chi soratniki. Inozemna mova u profesiyniy pidgotovtsi spetsialistiv: problemi ta strategiï: Zbirnik tez dopovidey II Mizhnarodnoï naukovo-praktichnoï internetkonferentsiï. - Kropivnits'kiy: RVV TsDPU imeni Volodimira Vinnichenka, 23-25.

Bigich O. B., Zaïka V. V. (2019). Analitichniy oglyad navchal'nikh materialiv «Tío Spanish: Aprender Español Online». Visnik KNLU. Seriya Pedagogika ta psikhologiya, Vip. 30, 2019, 196-202

Bigich, O. B. (2018b). Vibirkova distsiplina «Suchasni zasobi navchannya ispans'koï movi v zakladi seredn'oï osviti»: udoskonalennya metodichnoï kompetentnosti vchitelya. Aktual'ni pitannya gumanitarnikh nauk: Mizhvuzivs'kiy zbirnik naukovikh prats' molodikh vchenikh Drogobits'kogo derzhavnogo pedagogichnogo universitetu imeni Ivana Franka, 20( 1), 89-91.

Bigich, O. B. (2016). Metodichniy proekt dlya uchitelya pochatkovoï shkoli «Azbuka kvitiv - El abecedario de flores / The flowers ABC». Inozemni movi, 2015, 3, 45-52.

Bigich, O. B. (2012). Tío Spanish - virtual'niy uchitel' / vikladach ispans'koï movi. Inozemni movi, 2016, 2, 10-13.

Tarantino Parada V. (2019). 20 ideas y recursos para celebrar el Día del libro / Recuperado de https://www.laclasedeele. com/2019/04/20-ideas-y-recursos-para-celebrar-el.html

Escudero Álvarez F. (2020). Día del libro: unidad didáctica interactica / Recuperado de https://www.profedeele.es/ actividad/cultura/dia-del-libro-23-abril/

Отримано 24.06.2020 p. 